\title{
Evaluation of Resistance to Ergot, Caused by Claviceps purpurea, in Kentucky Bluegrass, Based on Incidence and Severity Estimates
}

\author{
Steve C. Alderman and Reed E. Barker, USDA-ARS, National Forage Seed Production Research Center, 3450 \\ SW Campus Way, Corvallis, OR 97331
}

\begin{abstract}
Alderman, S. C., and Barker, R. E. 2003. Evaluation of resistance to ergot, caused by Claviceps purpurea, in Kentucky bluegrass, based on incidence and severity estimates. Plant Dis. 87:1043-1047.

Ergot, caused by Claviceps purpurea, is an important disease of Kentucky bluegrass grown for seed. Resistance is a preferred means of disease control, although approaches to evaluating ergot resistance in Kentucky bluegrass are not well established. A large scale disease assessment trial was established to compare within-year and year-to-year variability among measures of ergot incidence or severity in Kentucky bluegrass and to determine the most efficient approaches for cultivar evaluation. The susceptibility of 104 Kentucky bluegrass cultivars ( 78 commercial and 26 experimental) to ergot was assessed, based on percentage of panicles with sclerotia (incidence), sclerotia per panicle (severity), percentage of seeds replaced by sclerotia, or percentage of sclerotia among seed by weight. Cultivar ranking for susceptibility within years was similar for all methods of ergot assessment. Yearly mean incidence of ergot among cultivars ranged from 1.0 to $97.5 \%$ for susceptible cv. HV102 to 0.0 to $2.5 \%$ for resistant cv. Huntsville, with remaining cultivars distributed between the extremes. Yearly mean values of ergot incidence and severity differed among years. Much of this variability was due to days with rain during the period from flower initiation to maturity (period of susceptibility). Disease incidence was correlated $(P \leq 0.05)$ with days with rain in 22 of the cultivars. Duration of flowering was correlated $(P \leq 0.05)$ with ergot incidence in 11 cultivars. Results from this study suggest that variability in host and environment would likely offset any gain in precision of severity data. In large trials in particular, collection of incidence data (percentage of panicles with ergot) would provide the most timely and efficient means for ergot assessment.
\end{abstract}

Additional keywords: Poa pratensis

Ergot, caused by Claviceps purpurea (Fr.:Fr.) Tul., is an important disease of grasses grown for seed. Ergot can be especially severe in Kentucky bluegrass (Poa pratensis L.) seed production, with yield losses estimated as high as $25 \%$ (2). Claviceps purpurea invades the ovary, replacing the potential seed with a hard black sclerotium. Sclerotia are typically one to several times longer than the host seed and black in color, making visual detection relatively easy. Spread of conidia of C. purpurea, which ooze from infected florets in a mixture of conidia and a sugary syrup derived from the plant sap (honeydew), can occur through seed head to seed head contact, rain splashing, or insect movements. The flower is the only organ infected (3).

Ergot control through fungicide application at flowering is possible but expensive.

Corresponding author: Steve Alderman

E-mail: aldermas@onid.orst.edu

Accepted for publication 2 April 2003.

Publication no. D-2003-0616-04R

This article is in the public domain and not copyrightable. It may be freely reprinted with customary crediting of the source. The American Phytopathological Society, 2003.
Host resistance is the preferred approach to disease control. However, few quantitative studies of resistance to ergot in Kentucky bluegrass are available, and there is little information concerning variability associated with different methods of ergot assessment. In the cereal grains, ergot has been assessed preharvest, as percentage of spikes with sclerotia (13), or percentage of florets with sclerotia $(4,7,10)$ or as postharvest estimates of percent sclerotia among seed by weight (9).

Expression of ergot in Kentucky bluegrass as percentage of flowers infected is difficult, since individual flowers are small and clustered into numerous tightly packed spikelets on panicles. Methods of disease assessment have included number of sclerotia per panicle (6) or per spikelet (5), sclerotial weight per panicle (6), percent seed replaced by sclerotia (2), or disease ratings of sclerotia or honeydew production (12). Cultivars vary in number of flowers per panicle and in timing and duration of flowering, potentially confounding disease resistance trials. Considerable yearto-year variation can occur, with wet conditions during flowering favoring disease development (1), although quantitative measures of variability are lacking. Information on year-to-year variability and within-year variability is needed for effective evaluation of commercial or experimental cultivars for resistance to ergot. In addition, an understanding of advantages and disadvantages of the various assessment methods appropriate for determining host resistance to ergot would facilitate selection of assessment methods for both reliability and efficiency. The objectives of this study were to determine if ranking of cultivars or experimental selections in terms of susceptibility to ergot varies depending on methods of disease assessment, to determine to what extent year-to-year variability can be accounted for by rainfall data, and to evaluate resistance among cultivars of Kentucky bluegrass to $C$. purpurea.

\section{MATERIALS AND METHODS}

Field plots. Cultivars of Kentucky bluegrass (78 commercial and 26 experimental, 104 total) were obtained from U.S. and European grass breeders. Cultivars were sown in germination boxes, and individual seedlings were transplanted to $4.0 \times 20.5$ $\mathrm{cm}$ plastic cone pots (Cone-tainers) filled with commercial potting soil mix. After about 2 months, two plants per block of each cultivar were transplanted to field plots in the fall of 1993 in a randomized complete block experiment with five replications. The field plot was established at the Hyslop experimental research farm near Corvallis, OR $\left(44^{\circ} 38^{\prime} \mathrm{N}, 123^{\circ} 12^{\prime} \mathrm{W}\right)$. The soil type was a Woodburn silt loam, a fine-silty, mixed, mesic; Aquultic Argixerolls, on 0 to $3 \%$ slopes. The plot area was fertilized by soil incorporation of $35.8 \mathrm{~kg}$ $\mathrm{N}, 15.4 \mathrm{~kg} \mathrm{P}, 29.7 \mathrm{~kg} \mathrm{~K}$, and $15.7{\mathrm{~kg} \mathrm{~S} h{ }^{-1}}^{-}$ applied as a complete blend prior to transplanting in 1993. Thereafter, fertilizer was applied in split applications: $33.1 \mathrm{~kg} \mathrm{~N}$, $17.8 \mathrm{~kg} \mathrm{P}$, and $31.1 \mathrm{~kg} \mathrm{~S} \mathrm{ha}^{-1}$ as a blend of ammonium phosphate (16-20-0) and ammonium sulfate (20-0-0-24) in fall (midNovember 1994, 1995, 1996, and 1997) and two applications of $61.6 \mathrm{~kg} \mathrm{~N} \mathrm{ha}^{-1}$ as urea in spring (early March and mid-April 1995, 1996, 1997, and 1998). Irrigation was applied immediately after transplanting and at short intervals thereafter in 1993 for establishment. Irrigation was not applied after 1993. Weeds were controlled with applications of $0.28 \mathrm{~kg}$ a.i. ha ${ }^{-1}$ of bromoxynil (3,5-dibromo-4-hydroxybenzonitrile) plus $0.28 \mathrm{~kg}$ a.i. ha ${ }^{-1}$ MCPA [(4chloro-2-methylphenoxy) acetic acid] after emergence and $2.24 \mathrm{~kg}$ a.i. $\mathrm{ha}^{-1}$ of diuron 
Table 1. Incidence percentage of seed heads with sclerotia of Claviceps purpurea among registered or experimental cultivars during 1994 through 1998

\begin{tabular}{|c|c|c|c|c|c|c|c|c|c|}
\hline \multirow[b]{2}{*}{ Cultivar } & \multicolumn{4}{|c|}{$\%$ seeds heads with sclerotia } & \multirow[b]{2}{*}{ 4-year mean } & \multicolumn{2}{|c|}{ Days with rain ${ }^{a}$} & \multicolumn{2}{|c|}{ Susceptible period $^{\mathrm{b}}$} \\
\hline & 1994 & 1996 & 1997 & 1998 & & $r$ & $P$ & $r$ & $P$ \\
\hline HV 102 & 51.5 & 48.0 & 1.0 & 97.5 & 49.5 & 0.70 & 0.29 & 0.98 & 0.02 \\
\hline Adelphi & 40.7 & 7.5 & 17 & 76 & 35.3 & 0.84 & 0.15 & 0.97 & 0.03 \\
\hline Eclipse & 43.7 & 0.5 & 44.0 & 50.0 & 34.6 & 0.99 & 0.01 & 0.51 & 0.49 \\
\hline Bristol & 37.0 & 2.0 & 22.5 & 70.0 & 32.9 & 0.95 & 0.05 & 0.80 & 0.20 \\
\hline $\operatorname{Re} 88$ & 31.5 & 3.0 & 2.5 & 73.0 & 27.5 & 0.98 & 0.01 & 0.93 & 0.07 \\
\hline 84-777 & 34.5 & 1.0 & 4.5 & 69.5 & 27.4 & 0.90 & 0.10 & 0.96 & 0.01 \\
\hline Unique & 25.5 & 0 & 33.5 & 45.0 & 26.0 & 0.96 & 0.04 & 0.61 & 0.39 \\
\hline Touchdown & 22.7 & 3.5 & 1.5 & 72.0 & 24.9 & 0.93 & 0.07 & 0.92 & 0.08 \\
\hline Destiny & 25.3 & 0 & 16.5 & 55.0 & 24.2 & 0.90 & 0.10 & 0.73 & 0.27 \\
\hline Able 1 & 34.7 & 2.0 & 8.0 & 51.0 & 23.9 & 0.96 & 0.04 & 0.62 & 0.37 \\
\hline B8-13 & 22.5 & 1.0 & 5.7 & 65.5 & 23.7 & 0.83 & 0.17 & 0.66 & 0.34 \\
\hline Monopoly & 22.6 & 0 & 23.1 & 47.5 & 23.3 & 0.30 & 0.70 & 0.85 & 0.15 \\
\hline Chateau & 17.1 & 12.5 & 4.0 & 58.5 & 23.0 & 0.97 & 0.03 & 0.56 & 0.44 \\
\hline Asset & 14.4 & 0 & 50.1 & 27.5 & 23.0 & 0.77 & 0.23 & 0.23 & 0.77 \\
\hline Majestic & 48.2 & 3.0 & 1.0 & 38.5 & 22.7 & 0.71 & 0.29 & 0.99 & 0.01 \\
\hline C 74 & 18.7 & 0 & 22.5 & 48.0 & 22.3 & 0.87 & 0.13 & 0.84 & 0.15 \\
\hline Aspen & 21.0 & 2.5 & 27.5 & 38.1 & 22.3 & 0.85 & 0.15 & 0.64 & 0.36 \\
\hline A7-187 & 22.5 & 2.1 & 3.0 & 61.5 & 22.3 & 0.98 & 0.02 & 0.89 & 0.11 \\
\hline Plush & 38.9 & 2.5 & 4.0 & 42.0 & 21.8 & 0.72 & 0.28 & 0.96 & 0.04 \\
\hline Julia & 32.5 & 0 & 6.0 & 47.5 & 21.5 & 0.85 & 0.14 & 0.97 & 0.03 \\
\hline Estate & 17.5 & 5.0 & 0 & 63.0 & 21.4 & 0.98 & 0.02 & 0.89 & 0.11 \\
\hline B8-106 & 23.0 & 1.5 & 2.0 & 58.4 & 21.2 & 0.98 & 0.02 & 0.85 & 0.15 \\
\hline America & 32.4 & 2.0 & 16.9 & 32.5 & 20.9 & 0.86 & 0.14 & 0.93 & 0.07 \\
\hline Minstrel & 9.5 & 4.5 & 10.5 & 58.5 & 20.8 & 0.88 & 0.12 & 0.76 & 0.24 \\
\hline Midnight & 12.7 & 0 & 38.0 & 28.0 & 19.7 & 0.47 & 0.53 & 0.96 & 0.03 \\
\hline Glade & 24.5 & 1.5 & 18.0 & 34.5 & 19.6 & 0.91 & 0.09 & 0.57 & 0.43 \\
\hline Sydsport & 37.5 & 3.6 & 2.0 & 33.5 & 19.1 & 0.74 & 0.26 & 0.90 & 0.10 \\
\hline Barzan & 18.4 & 0.5 & 1.0 & 54.5 & 18.6 & 0.94 & 0.06 & 0.84 & 0.16 \\
\hline Baron & 13.0 & 0.5 & 1.9 & 58.5 & 18.5 & 0.95 & 0.06 & 0.92 & 0.07 \\
\hline Engrapp 03-6-49-1 & 24.8 & 0 & 6.0 & 42.5 & 18.3 & 0.91 & 0.09 & 0.91 & 0.08 \\
\hline BA-13 & 11.3 & 0.5 & 7.0 & 53.5 & 18.1 & 0.99 & 0.001 & 0.77 & 0.23 \\
\hline Classic & 15.0 & 0.5 & 5.9 & 50.6 & 18.0 & 0.90 & 0.10 & 0.57 & 0.43 \\
\hline A 34 & 15.0 & 0 & 12.5 & 44.4 & 18.0 & 0.57 & 0.43 & 0.61 & 0.39 \\
\hline Cheri & 18.0 & 2.0 & 6.5 & 44.0 & 17.6 & 0.99 & 0.01 & 0.79 & 0.21 \\
\hline Ikone & 21.0 & 2.5 & 8.0 & 39.0 & 17.6 & 0.81 & 0.19 & 0.82 & 0.18 \\
\hline Leikva & 29 & 1.5 & 0.5 & 38.0 & 17.3 & 0.38 & 0.62 & 0.44 & 0.56 \\
\hline Haga & 14.1 & 0.5 & 3.0 & 51.0 & 17.2 & 0.87 & 0.13 & 0.71 & 0.29 \\
\hline H87-429 & 12.4 & 0 & 3.1 & 53.0 & 17.1 & 0.95 & 0.05 & 0.88 & 0.12 \\
\hline Challenger & 12.3 & 0.5 & 3.5 & 52.0 & 17.1 & 0.85 & 0.15 & 0.76 & 0.24 \\
\hline Suffolk & 15.5 & 2.1 & 3.0 & 47.5 & 17.0 & 0.86 & 0.14 & 0.77 & 0.23 \\
\hline Barblue & 10.5 & 0 & 5.5 & 52.0 & 17.0 & 0.70 & 0.29 & 0.60 & 0.39 \\
\hline Ampella & 19.0 & 0 & 8.5 & 39.5 & 16.7 & 0.70 & 0.30 & 0.71 & 0.29 \\
\hline Georgetown & 10.0 & 0 & 4.0 & 51.5 & 16.4 & 0.98 & 0.0 & 0.85 & 0.15 \\
\hline R-729 & 22.1 & 1.5 & 5.9 & 35.5 & 16.3 & 0.96 & 0.04 & 0.70 & 0.30 \\
\hline Platini & 26.4 & 0 & 3.5 & 35.0 & 16.2 & 0.81 & 0.19 & 0.93 & 0.07 \\
\hline Enmundi & 24.8 & 0.5 & 9.1 & 29.0 & 15.9 & 0.79 & 0.21 & 0.97 & 0.03 \\
\hline Banff & 13.2 & 1.5 & 2.0 & 46.5 & 15.8 & 0.96 & 0.04 & 0.76 & 0.24 \\
\hline Summit & 26.0 & 1.9 & 1.9 & 31.3 & 15.3 & 0.72 & 0.28 & 0.67 & 0.33 \\
\hline Dawn & 9.5 & 0.5 & 4.0 & 46.5 & 15.1 & 0.88 & 0.12 & 0.67 & 0.32 \\
\hline Freedom & 15.7 & 2.0 & 2.0 & 40.0 & 14.9 & 0.91 & 0.09 & 0.94 & 0.06 \\
\hline Sophia & 33.2 & 0.63 & 3.1 & 22.5 & 14.9 & 0.63 & 0.37 & 0.91 & 0.09 \\
\hline Nassau & 10.5 & 8.4 & 1.0 & 39.0 & 14.7 & 0.82 & 0.18 & 0.88 & 0.12 \\
\hline A7-341 & 17.5 & 2.0 & 4.5 & 32.5 & 14.1 & 0.94 & 0.06 & 0.96 & 0.04 \\
\hline Flyking & 18.0 & 2.5 & 4.0 & 32.0 & 14.1 & 0.89 & 0.11 & 0.99 & 0.01 \\
\hline Victa & 19.3 & 1.0 & 10.5 & 24.5 & 13.8 & 0.79 & 0.21 & 0.85 & 0.15 \\
\hline Merit & 17.0 & 2.5 & 10.0 & 24.5 & 13.5 & 0.95 & 0.05 & 0.92 & 0.08 \\
\hline Merion & 10.8 & 0.5 & 6.5 & 36.0 & 13.5 & 0.79 & 0.21 & 0.74 & 0.26 \\
\hline Gnome & 16.1 & 2.5 & 6.5 & 28.5 & 13.4 & 0.76 & 0.24 & 0.66 & 0.34 \\
\hline A83-285 & 20.0 & 0 & 0.5 & 33 & 13.4 & 0.85 & 0.14 & 0.93 & 0.06 \\
\hline Harmony & 34.5 & 1.3 & 0 & 17.5 & 13.3 & 0.28 & 0.79 & 0.54 & 0.46 \\
\hline Compact & 14.5 & 0.5 & 0.5 & 35.5 & 12.8 & 0.57 & 0.43 & 0.21 & 0.79 \\
\hline Yo 88 & 7.5 & 1.5 & 1.0 & 40.5 & 12.6 & 0.97 & 0.03 & 0.92 & 0.08 \\
\hline Trenton & 15.0 & 2.0 & 5.0 & 28.0 & 12.5 & 0.97 & 0.03 & 0.62 & 0.38 \\
\hline Aguila & 12.5 & 1.5 & 0.5 & 31.0 & 11.4 & 0.89 & 0.10 & 0.90 & 0.09 \\
\hline Geronimo & 12.5 & 1.0 & 0 & 31.5 & 11.3 & 0.77 & 0.23 & 0.89 & 0.11 \\
\hline Blacksburg & 16.0 & 0.5 & 0.5 & 27.0 & 11.0 & 0.80 & 0.20 & 0.96 & 0.04 \\
\hline Conni & 14.1 & 0.5 & 7.0 & 22.0 & 10.9 & 0.64 & 0.35 & 0.63 & 0.37 \\
\hline Engrapp 03-6-48-3 & 21.1 & 2.0 & 5.0 & 15.0 & 10.8 & -0.27 & 0.73 & -0.51 & 0.49 \\
\hline \multirow[t]{2}{*}{$\mathrm{R}-740$} & 8.5 & 1.0 & 2.5 & 31.0 & 10.8 & 0.85 & 0.14 & 0.91 & 0.09 \\
\hline & & & & & & & & \multicolumn{2}{|c|}{ (continued on next pag } \\
\hline
\end{tabular}

${ }^{a}$ Correlation $(r)$ between yearly mean incidence and days with rain between flower initiation and seed maturity (susceptible period) and probability value $(P)$ associated with the correlation.

${ }^{\mathrm{b}}$ Correlation $(r)$ and probability $(P)$ between incidence and length of susceptible period. 
Table 1. (continued from preceding page)

\begin{tabular}{|c|c|c|c|c|c|c|c|c|c|}
\hline \multirow[b]{2}{*}{ Cultivar } & \multicolumn{4}{|c|}{$\%$ seeds heads with sclerotia } & \multirow[b]{2}{*}{ 4-year mean } & \multicolumn{2}{|c|}{ Days with rain ${ }^{a}$} & \multicolumn{2}{|c|}{ Susceptible period $^{b}$} \\
\hline & 1994 & 1996 & 1997 & 1998 & & $r$ & $P$ & $r$ & $P$ \\
\hline Tendos & 9.4 & 5.0 & 1.0 & 26.5 & 10.5 & 0.85 & 0.15 & 0.74 & 0.25 \\
\hline Mystic & 13.2 & 1.3 & 0 & 26.5 & 10.2 & 0.48 & 0.52 & 0.76 & 0.24 \\
\hline Parade & 9.0 & 1.5 & 5.0 & 25.0 & 10.1 & 0.96 & 0.04 & 0.72 & 0.28 \\
\hline Cynthia & 9.1 & 1.5 & 0 & 28.0 & 9.7 & 0.94 & 0.06 & 0.92 & 0.08 \\
\hline Joy & 15.5 & 4.5 & 0 & 17.5 & 9.4 & 0.42 & 0.58 & 0.49 & 0.51 \\
\hline Marguis & 15.9 & 0.5 & 4.0 & 16.5 & 9.2 & 0.80 & 0.20 & 0.92 & 0.08 \\
\hline Ronde & 20.1 & 0.5 & 0 & 15.5 & 9.0 & -0.07 & 0.93 & 0.07 & 0.93 \\
\hline Hatfjelldal & 4.4 & 3.0 & 0.5 & 28.0 & 9.0 & 0.66 & 0.34 & 0.47 & 0.53 \\
\hline Kenblue & 15.5 & 14.1 & 0 & 5.5 & 8.8 & 0.15 & 0.85 & 0.41 & 0.59 \\
\hline Nutop & 4.5 & 0.5 & 0.5 & 28.5 & 8.5 & 0.96 & 0.04 & 0.89 & 0.11 \\
\hline Wabash & 10.0 & 0 & 2.5 & 20.0 & 8.1 & 0.92 & 0.08 & 0.93 & 0.07 \\
\hline Engrapp Conni & 10.3 & 0.5 & 6.0 & 14.5 & 7.8 & 0.80 & 0.20 & 0.80 & 0.21 \\
\hline Balin & 8.0 & 2.0 & 0.5 & 20.5 & 7.8 & 0.56 & 0.44 & 0.65 & 0.35 \\
\hline Nugget & 14.6 & 4.1 & 1.0 & 9.5 & 7.3 & 0.34 & 0.67 & 0.83 & 0.17 \\
\hline Ryss & 9.7 & 5.0 & 0 & 13.5 & 7.0 & 0.76 & 0.24 & 0.99 & 0.01 \\
\hline Kver 9009 & 5.0 & 0.6 & 6.0 & 16.0 & 6.9 & 0.97 & 0.03 & 0.62 & 0.38 \\
\hline Vaer 8703 & 16.0 & 0.5 & 1.0 & 8.0 & 6.4 & -0.78 & 0.31 & -0.62 & 0.38 \\
\hline Welcome & 6.9 & 1.5 & 1.5 & 14.5 & 6.1 & 0.85 & 0.14 & 0.89 & 0.11 \\
\hline Engrapp 03-6-54-4 & 4.5 & 0 & 2.5 & 17.0 & 6.0 & 0.97 & 0.03 & 0.76 & 0.24 \\
\hline Holt & 0 & 5.0 & 0 & 18.5 & 5.9 & 0.75 & 0.15 & 0.75 & 0.25 \\
\hline Engrapp 03-6-53-2 & 7.6 & 0 & 1.0 & 14.0 & 5.7 & 0.29 & 0.71 & 0.27 & 0.73 \\
\hline Kver 9021 & 2.5 & 2.0 & 0 & 18.0 & 5.6 & 0.82 & 0.18 & 0.62 & 0.35 \\
\hline Alene & 4.5 & 7.5 & 0 & 10.0 & 5.5 & 0.72 & 0.46 & 0.94 & 0.06 \\
\hline Columbia & 9.0 & 1.0 & 2.0 & 9.5 & 5.4 & 0.80 & 0.02 & 0.97 & 0.03 \\
\hline Ram 1 & 5.5 & 0.5 & 0 & 12.0 & 4.5 & 0.86 & 0.14 & 0.93 & 0.07 \\
\hline Lavang & 2.3 & 1.0 & 0.5 & 14.0 & 4.4 & 0.72 & 0.28 & 0.71 & 0.29 \\
\hline Limosine & 7.5 & 1.5 & 1.0 & 7.5 & 4.4 & 0.69 & 0.44 & 0.93 & 0.07 \\
\hline Vaer 8702 & 1.7 & 1.5 & 0 & 13.5 & 4.2 & 0.70 & 0.30 & 0.41 & 0.59 \\
\hline Birka & 9.5 & 0 & 1.0 & 5.0 & 3.9 & 0.53 & 0.20 & 0.96 & 0.05 \\
\hline Kver 9030 & 1.5 & 2.5 & 0.5 & 11.0 & 3.9 & 0.99 & 0.002 & 0.84 & 0.16 \\
\hline Amazon & 3.8 & 0 & 0.5 & 9.5 & 3.4 & 0.98 & 0.22 & 0.85 & 0.14 \\
\hline South Dakota & 10.5 & 0.5 & 0 & 2.5 & 3.4 & -0.63 & 0.28 & -0.49 & 0.51 \\
\hline Ginger & 0.5 & 2.0 & 0 & 3.0 & 1.4 & 0.98 & 0.37 & 0.78 & 0.22 \\
\hline Troy & 4.0 & 0.5 & 0 & 1.0 & 1.4 & -0.56 & 0.02 & -0.17 & 0.83 \\
\hline Huntsville & 2.5 & 0 & 0 & 0 & 0.6 & -0.36 & 0.64 & 0.05 & 0.95 \\
\hline LSD (0.05) & 15.36 & 6.74 & 7.67 & 21.62 & 6.94 & & & & \\
\hline
\end{tabular}

[N'-(3,4 dicholorophenyl)- $N, N$-dimethylurea] each fall.

Plant growth and ergot assessments were made during each spring from 1994 through 1998, except for 1995, when a severe stripe rust (caused by Puccina striiformis Westend) outbreak compromised the seed production and interfered with ergot development. In subsequent years, Tilt (1-[[2-(2,4-dichlorophenyl)-4 propyl1,3-dixolan-2-yl] methyl]-1H-1,2,4-triazole) $\left(0.3 \mathrm{ml}\right.$ a.i. $\left.\mathrm{ha}^{-1}\right)$ was applied prior to flowering for rust control. Plots were examined two to three times each week during the period from flower initiation to seed maturity, and the date of flower initiation, ending flowering, and seed maturity were noted for each plant.

Assessment of ergot. Four different methods of ergot assessment were based on 20 panicles from each of two plants in a plot (total 40 panicles per plot). Following enumeration of panicles with sclerotia, a rubbing block was used to hand thresh the panicles. Stem pieces and large debris were removed with hand screens. Large sclerotia or those stuck to debris from honeydew were removed and combined with sclerotia from other fractions. Fine debris was removed with an air column set to remove lightweight debris but not seed. The fractions were checked periodically to verify that no seed or sclerotia were lost. Sclerotia were removed by hand, counted, and weighed. After removal of sclerotia, the seed was weighed and a seed counter (Count-A-Pak model 701A, Martec Research, Inc., Batavia, IL) was used to separate 1,000 seed for determination of 1,000seed weight. Seed number was obtained by dividing total seed weight by individual seed weight, as determined from the 1,000 seed weight. Disease incidence was expressed as the percentage of panicles with sclerotia. Disease severity was quantified in terms of sclerotia per infected panicle (total number of sclerotia divided by total panicles with sclerotia in each 40-panicle sample), percentage of sclerotia based on seed number ([number of sclerotia divided by $\{$ number of seed + sclerotia $\}] \times 100$ ), or percentage of sclerotia based on seed weight (sclerotia weight divided by [sclerotia weight + seed weight] $\times 100$ ). Rainfall data were obtained from the Hyslop research farm weather station.

Statistical analysis. A square root transformation was made on all assessment data after checking for normality and heteroscedasticity. Transformed data were analyzed using the general linear models (GLM) procedure (11) to conduct an analysis of variance as repeated measures in a split-plot in time over 4 years (14).
Mean separations on antitransformed data were by $t$ tests and Fisher's least significant difference using the LSMEANS option of GLM. All effects except replications were considered random in the statistical model. Additional statistical analyses included analysis of covariance using PROC MIXED, and GLM was used for Spearman rank correlation and Pearson product moment correlation. The disease incidence covariate in covariance analysis was days with rain during the period of susceptibility. Spearman rank correlation was used to determine if ranking of cultivars for susceptibility within each year for each of the four assessment methods was significant. Spearman rank correlation was also used to determine if ranking of cultivars for susceptibility was significant across years for each of the assessment methods. Pearson product moment correlation was used to determine if yearly mean values of incidence for each cultivar were correlated with mean duration of the susceptible period for each corresponding cultivar or with the period of rainfall during the period of susceptibility (beginning of flowering to maturity) for each corresponding cultivar.

\section{RESULTS}

Yearly mean incidence of ergot among cultivars ranged from 1.0 to $97.5 \%$ for the 
Table 2. Partial analysis of variance (ANOVA) for square root transformed data for four disease assessment methods ${ }^{\mathrm{a}}$

\begin{tabular}{|c|c|c|c|c|c|}
\hline \multirow[b]{2}{*}{ Source } & \multirow[b]{2}{*}{ df } & \multicolumn{4}{|c|}{ Mean square } \\
\hline & & $\begin{array}{c}\% \text { Seed heads } \\
\text { with sclerotiab }^{b}\end{array}$ & $\begin{array}{c}\text { Sclerotia per } \\
\text { panicle }^{\mathrm{b}, \mathrm{c}}\end{array}$ & $\begin{array}{c}\% \text { Sclerotia by } \\
\text { number of seed }^{d}\end{array}$ & $\begin{array}{l}\% \text { Sclerotia by } \\
\text { seed weight }^{\text {b,e }}\end{array}$ \\
\hline Entry $^{\mathrm{f}}$ & 103 & $21.76 * *$ & $1.57^{* * *}$ & $0.41 * *$ & $1.33 * *$ \\
\hline Year $^{\mathrm{f}}$ & 3 & $2146.70 * *$ & $112.39 * *$ & $33.62 * *$ & $134.15^{* *}$ \\
\hline Entry $\times$ Year & 309 & $7.91 * *$ & $0.73 * *$ & $0.22 * *$ & $0.65 * *$ \\
\hline Residual & 1236 & 1.96 & 0.13 & 0.05 & 0.15 \\
\hline
\end{tabular}

${ }^{a}$ Disease assessment methods: disease incidence (\% seed heads with sclerotia), sclerotia/panicle, $\%$ sclerotia by number of seed, and \% sclerotia by seed weight in Kentucky bluegrass.

b Based on 40 panicles from each of five replicate plots. ** indicates significance at $P \leq 0.01$.

c (Total number of sclerotia divided by panicles with sclerotia) $\times 100$.

d Sclerotia number divided by (sclerotia number + seed number $) \times 100$.

e Sclerotia weight divided by (sclerotia weight + seed weight $) \times 100$.

${ }^{\mathrm{f}}$ Main effects were tested by Entry $\times$ Year.

Table 3. Yearly mean disease incidence and severity ${ }^{\mathrm{a}}$

\begin{tabular}{|c|c|c|c|c|c|}
\hline Year & $\begin{array}{l}\% \text { Seed heads } \\
\text { with sclerotia }^{b}\end{array}$ & $\begin{array}{l}\text { Sclerotia/ } \\
\text { panicle }^{\text {b,c }}\end{array}$ & $\begin{array}{c}\% \text { Sclerotia by } \\
\text { number of seed }^{\mathrm{d}}\end{array}$ & $\begin{array}{l}\text { \% Sclerotia by } \\
\text { seed weight }^{\mathrm{b}, \mathrm{e}}\end{array}$ & Rain days $^{f}$ \\
\hline 1994 & 16.8 & 0.45 & 0.05 & 0.20 & 12.8 \\
\hline 1996 & 2.2 & 0.56 & 0.06 & 0.17 & 10.5 \\
\hline 1997 & 5.8 & 0.37 & 0.19 & 0.49 & 13.3 \\
\hline 1998 & 33.9 & 2.14 & 0.60 & 2.30 & 19.1 \\
\hline LSD (0.05) & 1.4 & 0.15 & 0.07 & 0.15 & 0.3 \\
\hline
\end{tabular}

a Mean disease incidence (\% seed heads with sclerotia) and severity (sclerotia/panicle), (\% sclerotia/sclerotia and seed), and (\% sclerotia by seed weight) during 1994, 1996, 1997, and 1998.

$\mathrm{b}$ Based on 40 panicles from each of five replicate plots.

c (Total number of sclerotia divided by panicles with sclerotia) $\times 100$.

d Sclerotia number divided by (sclerotia number + seed number $) \times 100$.

e Sclerotia weight divided by (sclerotia weight + seed weight $) \times 100$.

${ }^{\mathrm{f}}$ Number of days with rain during the susceptible period.

highly susceptible HV102 to 0.0 to $2.5 \%$ for the resistant Huntsville (Table 1), with remaining cultivars distributed between the extremes. Sclerotia per panicle were up to 48 on HV102, equating to about $9 \%$ seed replaced by sclerotia or $21 \%$ sclerotia based on weight of seed plus sclerotia. Analysis of variance revealed significant differences $(P<0.0001)$ among cultivars and among years for each of the disease assessment methods and days with rain during the flowering period (Table 2). Considerable year to year variation in ergot incidence or severity was noted (Table 3 ).

The period of susceptibility for most of the cultivars extended from about calendar day 140 to day 170 . Fewer days with rain occurred during the susceptible period in 1996, compared with that in 1994, 1997, and 1998 (Fig. 1). Analysis of covariance indicated no significant effect among cultivars for ergot incidence adjusted for rain $(F=1.10, P=0.25)$, but cultivars responded differently to rain as indicated by a significant interaction $(F=2.47, P<$ 0.0001 ), indicating heterogeneity among cultivars for the relationship of incidence with days with rain during the susceptible period. Most of this variability was accounted for by days with rain $(F=70.86, P$ $<0.0001)$. Pearson product moment correlation calculated for each of the 104 cultivars indicated that ergot incidence was correlated $(P \leq 0.05)$ with days with rainfall during the susceptible period in 22 of the 104 cultivars (Table 1). Ergot incidence was correlated $(P \leq 0.05)$ with duration of the susceptible period in 11 of the cultivars (Table 1).

Spearman rank correlation analysis indicated that ranking of cultivars within each year among the four ergot assessment methods were significantly correlated $(P<$ 0.001) (Table 4). However, in examining year-to-year cultivar ranking for the four disease measurements (Table 5), 1996 was negatively correlated with 1997 and was not correlated with the other years, except for ergot by seed weight in 1994 and 1998.

\section{DISCUSSION}

Considerable variability in incidence and severity of ergot in Kentucky bluegrass was observed. In HV 102 for example, ergot incidence in 1996 and 1998 was 1 and $97.5 \%$, respectively. Our results suggest that rainfall (days with rain during the period of flowering) accounted for much of this variability. Rainfall occurred on almost twice as many days during the susceptible period in 1998 than in 1996. Although a significant effect of rainfall on incidence was noted in analysis of covariance, the effect was less dramatic when individual cultivars were examined. Environmental conditions, especially timing of rainfall, may have a confounding effect on comparison of cultivars when they have differences in the timing and duration of flowering and seed maturity. Although rankings did not differ significantly among the four measures of ergot, some shifts in ranking

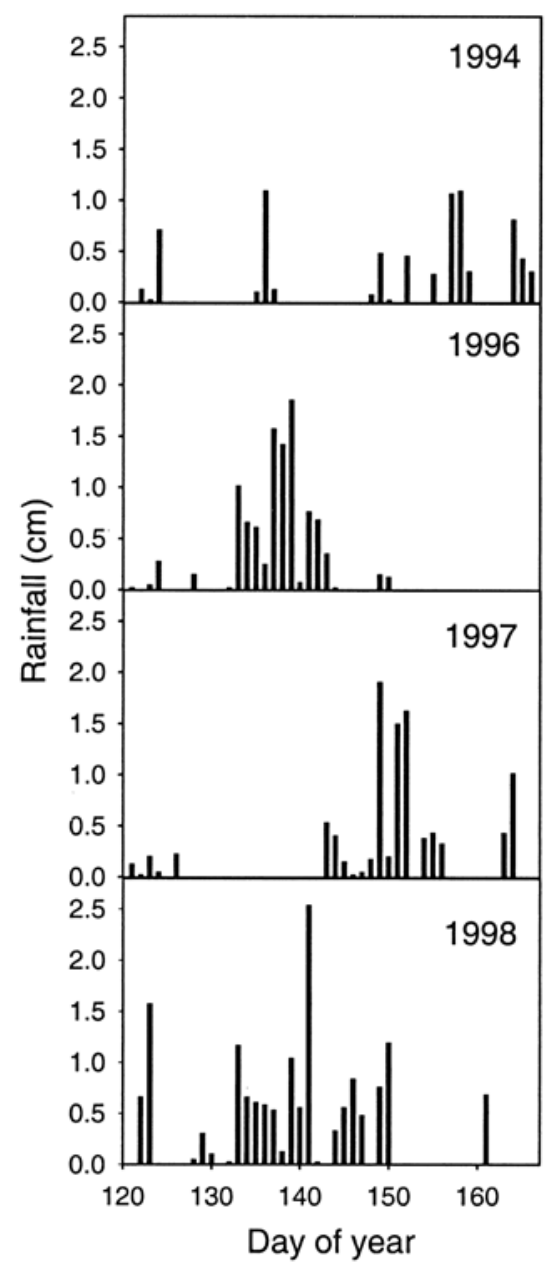

Fig. 1. Occurrence of rainfall during 1994 1996, 1997, and 1998 at Hyslop Research Farm, Corvallis, OR.

of individual cultivars could be expected depending on timing and duration of flowering in relation to occurrence of rainfall.

Previous studies demonstrated the effect of rainfall on production and release of ascospores $(1,8)$ that serve as primary inoculum. Within about 7 to 10 days of infection, conidia are produced and ooze from infected flowers in a mixture of conidia and a sugary syrup derived from the plant sap (honeydew). The contribution of conidia to disease development is believed to be facilitated by insects, but quantitative studies are lacking, and it is not clear to what extent insect transmission contributes to disease development.

Ergot incidence and severity assessments in Kentucky bluegrass can be confounded by cultivar variability in both number of panicles produced per plant and number of seed produced per panicle. In addition, sclerotia of $C$. purpurea were not distributed randomly among panicles but tended to cluster in variable numbers on individual panicles. Assessment of ergot based on individual panicles could be subject to variability from unequal distribution of sclerotia. Estimates based on incidence 
Table 4. Spearman rank correlations among ergot assessment methods within years of seed production $^{\mathrm{a}}$

\begin{tabular}{|c|c|c|c|}
\hline & $\begin{array}{c}\text { Sclerotia per } \\
\text { panicle }^{b}\end{array}$ & $\begin{array}{c}\text { Sclerotia by } \\
\text { seed number }\end{array}$ & $\begin{array}{l}\text { Sclerotia by } \\
\text { seed weight }\end{array}$ \\
\hline \multicolumn{4}{|l|}{1994} \\
\hline Panicles with sclerotia & $0.84 * *$ & $0.82 * *$ & $0.79 * *$ \\
\hline Sclerotia per panicle & & $0.87 * *$ & $0.81 * *$ \\
\hline Sclerotia by seed number & & & $0.89 * *$ \\
\hline \multicolumn{4}{|l|}{1996} \\
\hline Panicles with sclerotia & $0.73 * *$ & $0.76^{* *}$ & $0.76 * *$ \\
\hline Sclerotia per panicle & & $0.96 * *$ & $0.89 * *$ \\
\hline Sclerotia by seed number & & & $0.94 * *$ \\
\hline \multicolumn{4}{|l|}{1997} \\
\hline Panicles with sclerotia & $0.92 * *$ & $0.91 * *$ & $0.92 * *$ \\
\hline Sclerotia per panicle & & $0.99 * *$ & $0.95 * *$ \\
\hline Sclerotia by seed number & & & $0.96 * *$ \\
\hline \multicolumn{4}{|l|}{1998} \\
\hline Panicles with sclerotia & $0.84 * *$ & $0.72 * *$ & $0.84 * *$ \\
\hline Sclerotia per panicle & & $0.84 * *$ & $0.79 * *$ \\
\hline Sclerotia by seed number & & & $0.89 * *$ \\
\hline
\end{tabular}

a $* *=$ Significantly different from 0 at $P<0.01$.

$\mathrm{b}$ (Total number of sclerotia divided by panicles with sclerotia) $\times 100$.

c Sclerotia number divided by (sclerotia number + seed number $) \times 100$.

${ }^{\mathrm{d}}$ Sclerotia weight divided by (sclerotia weight + seed weight $) \times 100$.

Table 5. Spearman rank correlations among years for each of four ergot assessment methods

\begin{tabular}{|c|c|c|c|}
\hline & 1996 & 1997 & 1998 \\
\hline \multicolumn{4}{|c|}{ Panicles with sclerotia } \\
\hline 1994 & $0.06^{\mathrm{NSa}}$ & $0.46^{* *}$ & $0.56^{* *}$ \\
\hline 1996 & & $-0.21 * *$ & $0.05^{\mathrm{NS}}$ \\
\hline 1997 & & & $0.48 * *$ \\
\hline \multicolumn{4}{|c|}{ Sclerotia per panicle ${ }^{b}$} \\
\hline 1994 & $0.10^{\mathrm{NS}}$ & $0.37 * *$ & $0.41 * *$ \\
\hline 1996 & & $-0.28 * *$ & $0.05^{\mathrm{NS}}$ \\
\hline 1997 & & & $0.30 * *$ \\
\hline \multicolumn{4}{|c|}{ Sclerotia by seed number ${ }^{\mathrm{c}}$} \\
\hline 1994 & $0.11^{\mathrm{NS}}$ & $0.43 * *$ & $0.39 * *$ \\
\hline 1996 & & $-0.20 *$ & $0.19^{\mathrm{NS}}$ \\
\hline 1997 & & & $0.24^{*}$ \\
\hline \multicolumn{4}{|c|}{ Sclerotia by seed weight ${ }^{d}$} \\
\hline 1994 & $0.20 *$ & $0.34 * *$ & $0.45^{* *}$ \\
\hline 1996 & & $-0.19^{\mathrm{NS}}$ & $0.23 *$ \\
\hline 1997 & & & $0.32 * *$ \\
\hline
\end{tabular}

a NS $=$ not significantly different from 0 at $P<0.05 ; *$ Significantly different from 0 at $P<0.05 ; * *$ Significantly different from 0 at $P<0.01$.

$\mathrm{b}$ (Total number of sclerotia divided by panicles with sclerotia) $\times 100$.

c Sclerotia number divided by (sclerotia number + seed number $) \times 100$.

d Sclerotia weight divided by (sclerotia weight + seed weight $) \times 100$.

do not account for seed yield. Cultivars with either low or high seed yields may not reflect the number of flowers with sclerotia (disease severity). Although estimates of disease severity may provide more quanti- tative data than estimates of incidence, results from Spearman rank correlations indicated no significant difference in cultivar rankings among the assessment methods. This suggests no advantage of severity over incidence data in comparing cultivars. The extent of variability in host and environment likely overwhelm any gain in the precision of severity data. Since collection of incidence data is much faster and easier than determination of severity, incidence data provide a time and efficiency advantage in Kentucky bluegrass trials for ergot resistance. In large trials in particular, incidence (percentage of panicles with ergot) would provide the most timely and efficient means for ergot assessment.

\section{LITERATURE CITED}

1. Alderman, S. C. 1993. Aerobiology of Claviceps purpurea in Kentucky bluegrass. Plant Dis. 77:1045-1049.

2. Alderman, S. C., Coats, D. D., and Crowe, F. J. 1996. Impact of ergot on Kentucky bluegrass grown for seed in northeastern Oregon. Plant Dis. 80:853-855.

3. Bove, F. J. 1970. The story of ergot. S. Karger, Basel.

4. Bretag, T. W., and Merriman, P. R. 1980 Evaluation of Victorian wheat cultivars for resistance to ergot (Claviceps purpurea). Australas. Plant Pathol. 9:111-112.

5. Cagaš, B. 1996. Study of differential resistance of Kentucky bluegrass varieties to ergot [Claviceps purpurea (Fr.) Tul.]. Genet. a Šlecht. 32:161-168.

6. Chastain, T. G. 1992. Relationship of ergot to Kentucky bluegrass seed production and quality. J. Appl. Seed Prod. 10:7-10.

7. Cunfer, B. Mathre, D. E., and Hockett, E. A. 1974. Diversity of reaction to ergot among malesterile barleys. Plant Dis. Rep. 58:679-682.

8. Mantle, P. G., and Shaw, S. 1976. Role of ascospore production by Claviceps purpurea in aetiology of ergot disease in male sterile wheat. Trans. Br. Mycol. Soc. 67:17-22.

9. Pageau, D., Collin, J., and Wauthy, J. M 1994. Evaluation of barley cultivars for resistance to ergot fungus, Claviceps purpurea (Fr.) Tul. Can. J. Plant Sci. 74:663-665.

10. Platford, R. G., and Bernier, C. C. 1970. Resistance to Claviceps purpurea in spring and durum wheat. Nature 226:770.

11. SAS Institute Inc. 1989. SAS/STAT users guide. Version 6.12. 4th ed. SAS Inst. Inc., Cary, NC.

12. Schultz. T. R., Johnston, W. J., Golob. C. T., and Maguire, J. D. 1993. Control of ergot in Kentucky bluegrass seed production using fungicides. Plant Dis. 77:685-687.

13. Seymour, E. K., and McFarland, F. T. 1921. Loss from rye ergot. Phytopathology 11:285289.

14. Snedecor, G. W., and Cochran, W. G. 1980. Statistical methods. 7th ed. Iowa State Univ. Press, Ames, IA 